\title{
JOB SATISFACTION, LEADER-MEMBER EXCHANGE, AND ORGANIZATIONAL CITIZENSHIP BEHAVIOR AMONG MOTORCYCLE SALESPERSONS IN JAKARTA
}

\author{
Baskoro Bimmo Dwi ${ }^{\star}$, Sudarmadji, Suherman, Yani Ahmad, Jayadi, \\ Simanjuntak Robby \\ Sekolah Tinggi Manajemen Labora, Jakarta, Indonesia \\ *E-mail: bimmodibi@gmail.com
}

\begin{abstract}
This research aimed to assess the effects of Leader-Member Exchange (LMX) on Organizational Citizenship Behavior (OCB) which was directed to colleagues, and meditation of job satisfaction between those correlations. The respondents of this research were 300 employees who worked as salespersons riding on 2 wheeled vehicles or motorcycle in Jakarta. The assessment result used PLS-SEM. It showed that LMX had the significant effects to OCB directed to colleagues. LMX affected to job satisfaction. It affected to OCB which was directed to colleagues. Job satisfaction mediated the effects of LMX to OCB directed to colleagues. Based on the result of this research, the company needed to elevate the quality of correlation among supervisors, employees, and colleagues, for instance, conducting a training activity for them.
\end{abstract}

\section{KEY WORDS}

LMX, OCB, job satisfaction, motorcycle salespersons.

One of career fields which need the crucial role of company sales is a salesperson. The employee who works as a salesperson has a high job demand. (Darrat, Atinc, \& Babin, 2016) and has an excellent product knowledge (Y. Wang, Han, Xiang, \& Hampson, 2019) to satisfy his costumer (Itani \& Inyang, 2015). The high job demand can cause work stress (Geldart et al., 2018). Hence, salesperson may need a care, attention from the other salespersons and these will ease the hard situation of work among them. Eventough this is beyond of work description and voluntary behavior, the salesperson behavior to notice and give care for colleagues becomes essential. In behavioral study, the voluntary behavior and beyond of this work description have been analyzed as an Organzational Citizenship Behavior (OCB) construct. It is mainly directed to another individual at work (OCB-U/OCBIndividual) (Williams \& Anderson, 1991). OCB is a vital part of company performance (Mekpor \& Dartey-Baah, 2019). Meanwhile, the research in accordance with OCB of salespersons directed to colleagues is still rare and the researchers do not pay attention to this.

OCB is voluntary behavior of an individual to increase company performance (Podsakoff, Whiting, Podsakoff, \& Blume, 2009). Social support comes from supervisors and colleagues having an important role on work behavior such as OCB (Chênevert, Vandenberghe, \& Tremblay, 2015). Based on social exchange theory), that is the interaction between parties which depend to each other can show the reciprocal obligation (Cropanzano \& Mitchell, 2005). Thus, it can be said that an individual who accepts supervisor's kindness such as experiencing high quality relation with senior worker (leader-member exchange/LMX) and support from colleagues can possibly give reciprocal result by showing the OCB.

Ilies et al. (2007) in meta-analytic research it shows the various researches which have assessed the correlation between LMX and OCB. However, there are few different results, for example, the case related to the connection power from both subjects llies et al. (2007). Other than that, few researches tend to use general OCB measurement which includes OCB with organization target and the other individuals in an organization. It refers to llies et al. (2007), on LMX and OCB assessment, the use of different OCB type may provide the different result in LMX and OCB correlation. 
On its progress, few researches have assessed the correlation between LMX an OCB by considering mediator variables as the mechanism of LMX and OCB existence which probably occur. Those mediator variables, such as an employee's envy (Kim et al., 2010), organizational fairness (Kim et al., 2010), and perceive insider (L. Wang et al., 2010), these researches show that mediator variables have powerful and significant role as the correlation mechanism between LMX and OCB. One of those factors used by few researches as mediator variable on the correlation between an antecendent and OCB is job satisfaction. It refers to Mallin et al. (2017), job satisfaction of salespersons is determined by positive correlation between colleagues and supervisors. For the mean time, Paillé et al. (2016) state that an individual who obtains support from his colleagues will be satisfied and he provides his reciprocation by helping the other employees. Nevertheless, there are merely few researches which investigate this mechanism (Paillé et al., 2016), it includes salespersons context. This research contributes to deliver the knowledge of correlation between LMX and OCB directed to colleagues, and between colleague supports and OCB directed to colleagues. Also, it analyzes the mechanism of correlations occurrence by considering job satisaftion as mediator variables on saleperson context. This research aims to analyze the effects of LMX and OCB to motorcycle salaesperson OCB in Jakarta directed to colleagues with job satisfaction mediation.

\section{LITERATURE REVIEW AND HYPOTHESIS DEVELOPMENT}

Organizational Citizenship Behavior (OCB) is voluntary behavior accomplished by an individual and to support task performance at work. However, it is not explicitly recognized as a formal company appreciation (Podsakoff et al., 2009). Furthermore, OCB is considered as an extra-role behavior to distinguish an appropiate behavior when an employee is tasked at work (in-role) (Williams \& Anderson, 1991). OCB has few targets, one of these targets is the party which is an individual behavior destination, for instance, the other individuals namely colleagues (Podsakoff et al., 2009). OCB form directed to colleagues can be in various ways, for example, helping the colleagues in trouble, reducing interpersonal conflicts, giving support, information, and solution from the related to the problem (Salehzadeh et al., 2015), showing care and willing to listen to colleagues' problem (Williams \& Anderson, 1991).

Leader-Member Exchange (LMX) is a reciprocal correlation and share (it can be enjoyment or misfortune) between the supervisor and employee (Scandura et al., 1986). Referring to LMX theory, supervisor creates a diferrent relation with employee and there is a group of employees which experinces the high quality relation with their supervisors (called as in-group) and the other groups experience the low quality relation (called as out-group) (Yukl, 1989). The different quality of this relation happens among employees in a work unit with the same supervisor (Schriesheim et al., 1999). The difference is the employees who have high quality relation they acquire more sources, such as information, trust, chance from their supervisors than the employees having low quality relation (Shu \& Lazatkhan, 2017). Furthermore, the employees who experience high quality relation with their supervisors will obtain luck and valuable source from their supervisors (Kim et al., 2010).

Referring to social exchange theory, an individual who obtains good treatment from the supervisor or colleagues will give a positive reciprocation by doing OCB (llies et al., 2007). Wang et al. (2017) found that LMX has positive correlation with employees OCB in hospitality industry. The result of research Hackett et al. (2018) it shows that LMX has significantly positive correlation with OCB. Based on theory and the findings, it can be concluded that the more an individual experiences a positive relation with his supervisor, namely high LMX. An individual will accomplish more OCB directed to colleagues. This becomes a reciprocal form due to the good treatment. Based on the explanation above, the hypothesis is formulated as follows:

H1: LMX has positive effects to OCB directed to colleagues.

Job satisfaction is an evaluation result or individual affective reaction from his work (Wagner, 2017). This can be interpreted as a feeling due to the fulfillment of his need and desire (Arianti et al., 2020). An individual experiences a good treatment from supervisor and 
he will be satisfied (Wnuk, 2017). Referring to Akdol \& Arikboga (2017) research, it found that LMX has positive effects to job satisfaction. Thus, it can be concluded that the more an individual experiences a positive treatment, the more an individual will be satisfied. Based on the explanation above, hypothesis is formulated as follows:

H2: LMX has positive effects to job satisfaction.

An individual who is in a good mood he will help the other people more. For example, this individual does OCB to the other employees at work (Lee \& Allen, 2002). Yu et al. (2018) stated that an individual who experiences job satisfaction will provide his source for an organization, such as an extra-role behavior involvemet. Empirically, job satisfaction has positive effects to OCB directed to colleagues (Yu et al., 2018). Hence, it can be concluded that the higher job satisfaction is a higher involvement on OCB. Based on the explanation above, the hypothesis is formulated as follows:

H3: Job satisfaction has positive effects to OCB directed to colleagues.

The correlation between colleagues support and job satisfaction can cause reciprocal responsibility from an individual. That is replying the other people help (Paillé et al., 2016). Similarly, an individual who experiences high quality relation from supervisor will be satisfied and the job satisfaction will drive an individual to finish OCB (Cropanzano \& Mitchell, 2005; Dalal, 2005). Based on the theories and findings, it can be concluded that the more an individual experiences a positive relation with his supervisor namely high LMX, he will show more OCB directed to colleagues. This becomes a reciprocal form due to the good treatment. An individual experiencing a good treatment and he can fulfill his needs, for instance, obtaining the trust and support from supervisor and colleagues. He will be satisfied. Additionally, an individual who experiences more job satisfaction, he will be more optimal to accomplish OCB. It includes the subject directed to his colleagues. Based on the explanation above, the hypothesis is formulated as follows:

H4: Job satisfaction mediates the effects of $L M X$ to OCB directed to colleagues.

The correlation among the hypothesized variables LMX, JS, and OCB, they can be shown on research model of Figure 1.

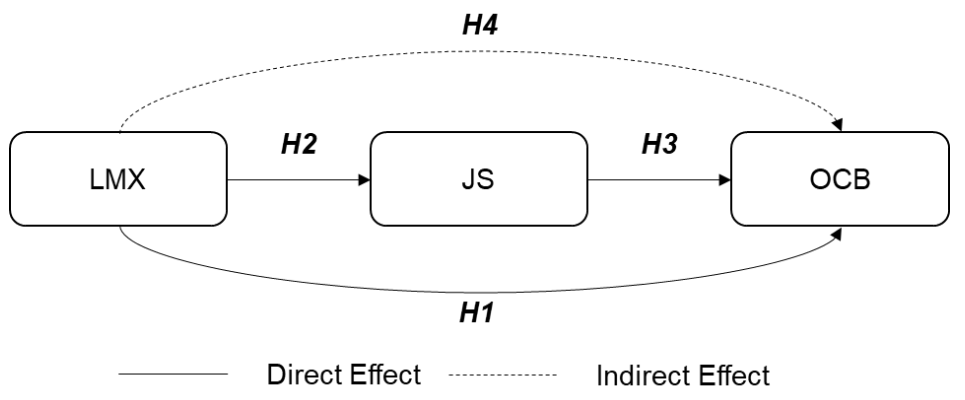

Figure 1 - Research Framework

\section{METHODS OF RESEARCH}

This research used data collection by distributing convenience random sampling-based questionnaire. The distribution of questionnaire was accomplished by the research assistant who directly analyzed the non-managerial employees. They worked as motorcycle salespersons in Jakarta. The salespersons job had a high work demand since they were the most advanced company representatives for consumer. Therefore, the employees who work on this section were expected to perform positive attitude at work, such as being supportive among colleagues in order to achieve high performance. The data collection was conducted anonymously. As an effort to make the respondents give their responds to this survey, therefore they were asked to put their complete questionnaires to the return envelopes that were provided. Therefore, the envelopes were returned to the research assistant in a sealed form. The data that was collected and able to be analyzed for hypothesis test with 300 respondents (with 75\% responds). Based on the data, the major respondents were women 
(57.7\%), at the age of $18-25$ years old $(47.4 \%)$, employed for $<5$ years $(87.2 \%)$, unmarried (76.3\%), and obtained bachelor degree (S1) (59\%).

LMX was measured with seven LMX indicator used in the research Wayne et al. (1997). Job satisfaction was measured with three indicators used in the research Randall et al. (1999). OCB that was directed to the colleagues was measured with four OCB-I indicators (OCB that was directed to an individual in organization) from Williams \& Anderson (1991). Respondents were asked to respond to the likert scale of 5 point $(1=$ strongly disagree -5 strongly agree).

This study used PLS-SEM and assisted by SmartPLS 3.2.8 to analyze the data. The data analysis included measurement model tests, such as reliability and validity tests, and also structural model test to test the hypothesis.

\section{RESULTS OF STUDY}

The measurement and structural model tests were conducted by using PLS-SEM. The assessment included variability test that were reflected in composite reliability (CR) value, and convergent validity test; outer loading value and average variance extracted (AVE) value, and discriminant validity test. In validity and reliability tests process, there were indicators that had to be deducted and unapplied in the future analysis. The test result in Table 1 showed that all of outer loading in each indicator obtained more than 0.50 values, AVE obtained more than 0.50 values, and CR obtained more than 0.80 values. Additionally, the result of discriminant validity test used Fornell-Larcker Criterion method (Fornell \& Larcker, 1981) indicate that all values of AVE square root were higher than correlation value between variables. Therefore, it can be said that the available data was fulfilled the validity and reliability requirements Hair et al. (2019). The result of discriminant validity test was shown in Table 2.

Table 1 - Convergent Validity

\begin{tabular}{|c|c|c|c|c|c|}
\hline Variable & Indicator & Outer Loading & $\mathrm{Ca}$ & CR & AVE \\
\hline \multirow[t]{6}{*}{ LMX } & LMX1 & 0.784 & 0.859 & 0.895 & 0.587 \\
\hline & LMX2 & 0.773 & & & \\
\hline & LMX4 & 0.783 & & & \\
\hline & LMX5 & 0.775 & & & \\
\hline & LMX6 & 0.747 & & & \\
\hline & LMX7 & 0.733 & & & \\
\hline \multirow[t]{3}{*}{ JS } & JS1 & 0.853 & 0.767 & 0.864 & 0.68 \\
\hline & JS2 & 0.866 & & & \\
\hline & JS3 & 0.750 & & & \\
\hline \multirow[t]{4}{*}{ OCB } & OCB1 & 0.724 & 0.791 & 0.864 & 0.615 \\
\hline & OCB2 & 0.837 & & & \\
\hline & OCB3 & 0.849 & & & \\
\hline & OCB4 & 0.717 & & & \\
\hline
\end{tabular}

Note: $n=300 ; C \alpha=$ Cronbach's alpha; $C R=$ Composite Reliability; AVE = Average Variance Extracted.

Table 2 - Discriminant Validity

\begin{tabular}{llll}
\hline Variable & JS & LMX & OCB \\
\hline JS & 0.824 & & \\
LMX & 0.436 & 0.766 & 0.784 \\
OCB & 0.624 & 0.593 & 0.783 \\
\hline
\end{tabular}

The result of structural model test showed that $19 \%$ variants in job satisfaction were able to be explained by LMX. Besides, it was shown that $51.6 \%$ variants in job satisfaction were able to be explained by OCB. The result of structural model test was reflected in Figure 2. Besides, the result of hypothesis in Table 3 showed that LMX significantly affected OCB directed to colleagues $(B=0.396, p<0.05)$. Thus, hypothesis 1 was supported. This research discovered that $L M X$ significantly affected job satisfaction in a positive way $(B=$ $0.436, p<0.05)$. Thus, hypothesis 2 was supported. The test result was also shown that job 
satisfaction significantly affected OCB in a positive way $(B=0.451, p<0.05)$. Thus, hypothesis 3 was supported.

Additionally, this research conducted a further analysis on indirect correlation between LMX and OCB, namely mediation role on job satisfaction. The test result showed that job satisfaction significantly mediated the correlation between LMX and OCB directed to colleagues $(ß=0.197, p<0.05)$. Thus, hypothesis 4 was supported.

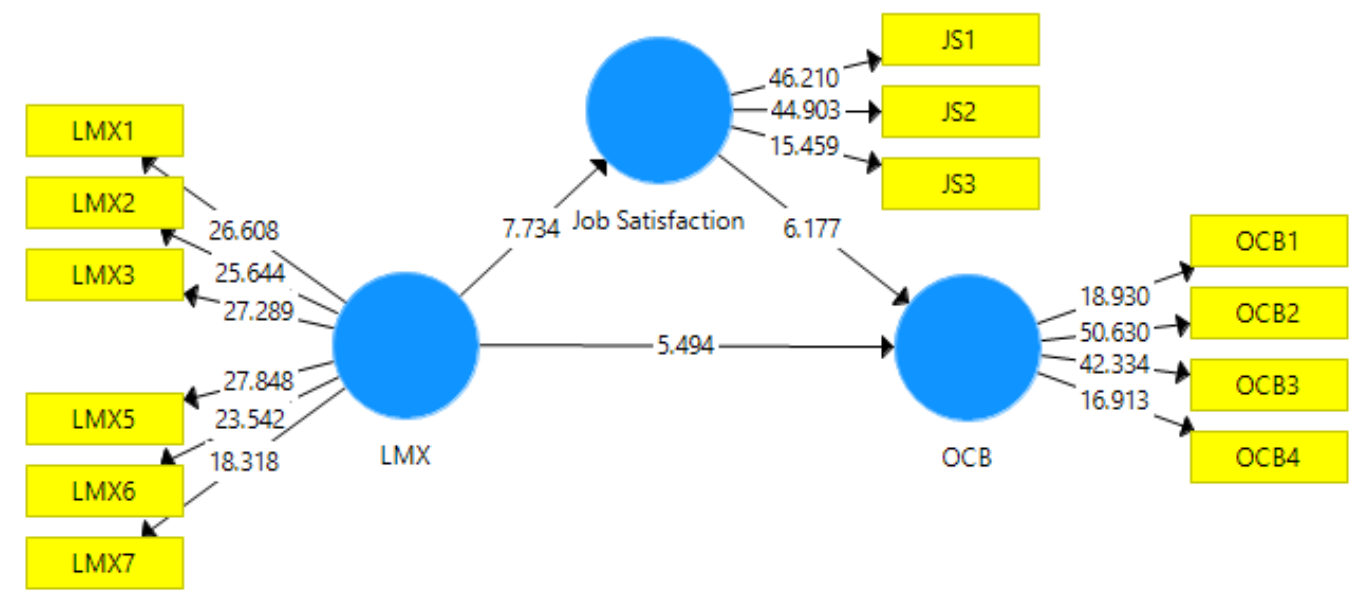

Figure 2 - Structural Model Result

Table 3 - Hypothesis Test Result

\begin{tabular}{llllll}
\hline Hypotheses & Relationship & Beta & $t$ statistics & $p$ value & Comment \\
\hline H1 & LMX $\rightarrow$ OCB & 0.396 & 5.494 & $0.000^{*}$ & Supported \\
H2 & LMX $\rightarrow$ JS & 0.436 & 7.734 & $0.000^{*}$ & Supported \\
H3 & JS $\rightarrow$ OCB & 0.451 & 6.177 & $0.000^{*}$ & Supported \\
H4 & LMX $\rightarrow$ JS $\rightarrow$ OCB & 0.197 & 4.173 & $0.000^{*}$ & Supported \\
\hline
\end{tabular}

Note: ${ }^{*} p<0.05$.

\section{DISCUSSION OF RESULTS}

In connection with the principle of social exchange theory, the findings of this research supported hypothesis 1 where LMX has positive effects to OCB that is directed to colleagues. Furthermore, this research discovers that individuals have high quality relation with their supervisorss (high LMX) will get better job satisfaction and show citizenship behavior that are directed to their colleagues. This finding also supports hypothesis 2 where LMX has positive effects to job satisfaction. It also supports hypothesis 3 where job satisfaction has positive effects to OCB that are directed to colleagues. Moreover, it supports hypothesis 4 where job satisfaction mediates the effects of LMX to OCB that are directed to colleagues. These findings show that individuals with high LMX will reflect their OCB, but they need to get their job satisfaction before conducting OCB. The problem is, even though LMX referred to the relationship between individuals/employees and their supervisorss. It is clear that they use the important benefits and sources from their supervisors, they will voluntarily concern and assist their colleagues. In the workplace, individuals/employees usually have social network with everyone from various work units (Sparrowe \& Liden, 1997) and be bond with them (Omilion-Hodges \& Baker, 2013). Individuals with high LMX will find it easier to obtain important information and resources from their supervisorss. Thus, the individuals will provide better assistance to their colleagues in organizational social networks. Additionally, if employees have higher quality relation with their supervisorss, the employees will obtain better work opportunity, flexibility, and autonomy (Hackett et al., 2018). These benefits can fulfill individuals' need or desire (Sparrowe \& Liden, 1997) that satisfy them. As a consequence, individuals will be eager to voluntarily assist other people at work. 
OCB is a behavior that conducted whether voluntarily or not and has no sanction elements in it (Mekpor \& Dartey-Baah, 2019). Therefore, there are few employees who do not need to reassist the other employees with OCB. Even though they have received support at work from their colleagues. Furthermore, individuals will probably experience a condition where the support of supervisors can increase their work completion better than other colleagues (Vera et al., 2016), therefore the assistance of colleagues is not an important matter that need to re-assist with OCB. Besides, few employees who do not receive any assistance at work, they are able to conduct OCB to their colleagues if they are willing to do it (voluntarily). Additionally, employees need to fulfill and satisfy their expectation of their colleagues' assistance. Therefore, it will help them to reassist with OCB, as shown in other findings concerning the mediation role on job satisfaction.

Referring to Wagner (2017), job satisfaction includes cognitive or faith elements, and affection or emotion concerning the work factors. Individuals that experiences job satisfaction with emotion/affection elements will be eager to conduct OCB directed to other individuals at work (Wagner, 2017). In conclusion, it can be said that individuals who experiences social support from their colleagues will conduct assessment for a support. If they are satisfied with affection, for example, the support of their colleagues make them feel less anxious or scared to face problems at work, therefore they will reassist it with OCB that is directed to their colleagues.

\section{CONCLUSION AND LIMITATIONS}

The current research aims to analyze the effects of LMX to OCB of motorcycle salespersons that are directed to colleagues with job satisfaction mediation. The findings of this research show that in order to increase the OCB of motorcycle salespersons to colleagues, it needs job satisfaction, support from colleagues, and high quality relation between employees and supervisors. This finding is consistent with the principle of social exchange theory having positive treatment of one party to another party will drive another party to provide positive feedback as well. This research enriches the understanding that supervisors play an important role in increasing willingness of employees, in order to voluntarily assist their colleagues. The higher LMX, the more it drives individuals to be involved in OCB that is directed to colleagues. Besides, job satisfaction also plays an important role as a communication mechanism on the effects of LMX to OCB that is directed to colleagues.

In relation with these research findings, there are several practical suggestions for company and manager. First, company should conduct activities that can improve the relation quality among employees, and between supervisors and employees. Second, manager is required to comprehend the importance of providing support to motorcycle salespersons, for example, by providing clear information and simple access to be contacted by employees. Bearing in mind that motorcycle salespersons are demanded to frequently interact with customers, including handling complaints and creating quick decision to satisfy customers. Third, providing the role understanding and training to motorcycle salespersons to give the understanding that each salesperson needs to support each other, specifically when they work in a team.

Besides the interesting findings, this research can not be separated with any limitations that need to be concerned in future research. First, the data used in this research are the results of respondents' self-report. However, the variables of this research, namely LMX and job satisfaction are perception regarding personal experience and feeling as the result of personal assessment. Therefore, the use of self-report can be an alternative way to collect this data. Second, this research uses cross-sectional data, therefore the future research needs to consider the use of longitudinal study design. Third, the research model is tested by using a sample that is limited to one work field, namely salesperson. Thus, the future research may consider different samples which are unique and they can be generalized. 


\section{REFERENCES}

1. Akdol, B., \& Arikboga, F. S. (2017). Leader member exchange as a mediator of the relationship between servant leadership and job satisfaction: A research on Turkish ICT companies. International Journal of Organizational Leadership, 6(4), 525-535. https://doi.org/10.33844/ijol.2017.60226.

2. Arianti, W. P., Hubeis, M., \& Puspitawati, H. (2020). Pengaruh Faktor Kepuasan Kerja terhadap Employee Engagement di Perwiratama Group. Jurnal Manajemen Teori \& Terapan, 13(1), 31-48. https://doi.org/http://dx.doi.org/10.20473/jmtt.v13i1.14889.

3. Chênevert, D., Vandenberghe, C., \& Tremblay, M. (2015). Multiple sources of support, affective commitment, and citizenship behaviors: The moderating role of passive leadership. Personnel Review, 44(1), 69-90. https://doi.org/10.1108/PR-08-2012-0144.

4. Cropanzano, R., \& Mitchell, M. S. (2005). Social exchange theory: An Interdisciplinary review. Journal of Management, 31(6), 874-900. https://doi.org/10.1177/0149206305279602.

5. Dalal, R. S. (2005). A meta-analysis of the relationship between organizational citizenship behavior and counterproductive work behavior. Journal of Applied Psychology, 90(6), 1241-1255. https://doi.org/10.1037/0021-9010.90.6.1241.

6. Darrat, M., Atinc, G., \& Babin, B. J. (2016). On the dysfunctional consequences of salesperson exhaustion. Journal of Marketing Theory and Practice, 24(2), 236-245. https://doi.org/10.1080/10696679.2016.1130563.

7. Fornell, C., \& Larcker, D. F. (1981). Structural Equation Models with Unobservable Variables and Measurement Error: Algebra and Statistics. Journal of Marketing Research, 18(3), 382. https://doi.org/10.2307/3150980.

8. Geldart, S., Langlois, L., Shannon, H. S., Cortina, L. M., Griffith, L., \& Haines, T. (2018). Workplace incivility, psychological distress, and the protective effect of co-worker support. International Journal of Workplace Health Management, 11(2), 96-110. https://doi.org/10.1108/IJWHM-07-2017-0051.

9. Hackett, R. D., Wang, A. C., Chen, Z., Cheng, B. S., \& Farh, J. L. (2018). Transformational Leadership and Organisational Citizenship Behaviour: A Moderated Mediation Model of Leader-Member-Exchange and Subordinates' Gender. Applied Psychology, 67(4), 617-644. https://doi.org/10.1111/apps.12146.

10. Hair, J. F., Sarstedt, M., \& Ringle, C. M. (2019). Rethinking some of the rethinking of partial least squares. European Journal of Marketing, 53(4), 566-584. https://doi.org/10.1108/EJM-10-2018-0665.

11. Ilies, R., Nahrgang, J. D., \& Morgeson, F. P. (2007). Leader-member exchange and citizenship behaviors: A meta-analysis. Journal of Applied Psychology, 92(1), 269-277. https://doi.org/10.1037/0021-9010.92.1.269.

12. Itani, O. S., \& Inyang, A. E. (2015). The effects of empathy and listening of salespeople on relationship quality in the retail banking industry: The moderating role of felt stress. International Journal of Bank Marketing, 33(6), 692-716. https://doi.org/10.1108/IJBM-062014-0076.

13. Kim, S., O'Neill, J. W., \& Cho, H. M. (2010). When does an employee not help coworkers? The effect of leader-member exchange on employee envy and organizational citizenship behavior. International Journal of Hospitality Management, 29(3), 530-537. https://doi.org/10.1016/j.ijhm.2009.08.003.

14. Lee, K., \& Allen, N. J. (2002). Organizational citizenship behavior and workplace deviance: the role of affect and cognitions. The Journal of Applied Psychology, 87(1), 131-142. https://doi.org/10.1037/0021-9010.87.1.131.

15. Mallin, M. L., Gammoh, B. S., Pullins, E. B., \& Johnson, C. M. (2017). A New Perspective of Salesperson Motivation and Salesforce Outcomes: The Mediating Role of Salesperson-Brand Identification. Journal of Marketing Theory and Practice, 25(4), 357374. https://doi.org/10.1080/10696679.2017.1345597.

16. Mekpor, B., \& Dartey-Baah, K. (2019). Voluntary workplace behaviors among employees of high and low-performing banks: A comparative study of selected banks in Ghana's 
Club 100. International Journal of Organizational Analysis, 27(1), 2-18. https://doi.org/10.1108/lJOA-06-2017-1179.

17. Omilion-Hodges, L. M., \& Baker, C. R. (2013). Contextualizing LMX within the workgroup: The effects of LMX and justice on relationship quality and resource sharing among peers. Leadership Quarterly, 24(6), 935-951. https://doi.org/10.1016/j.leaqua.2013.10.004.

18. Paillé, P., Mejía-Morelos, J. H., Marché-Paillé, A., Chen, C. C., \& Chen, Y. (2016). Corporate Greening, Exchange Process Among Co-workers, and Ethics of Care: An Empirical Study on the Determinants of Pro-environmental Behaviors at CoworkersLevel. Journal of Business Ethics, 136(3), 655-673. https://doi.org/10.1007/s10551-0152537-0.

19. Podsakoff, N. P., Whiting, S. W., Podsakoff, P. M., \& Blume, B. D. (2009). Individual- and Organizational-Level Consequences of Organizational Citizenship Behaviors: A MetaAnalysis. Journal of Applied Psychology, 94(1), 122-141. https://doi.org/10.1037/a0013079.

20. Randall, M. L., Cropanzano, R., Bormann, C. A., \& Birjulin, A. (1999). Organizational politics and organizational support as predictors of work attitudes, job performance, and organizational citizenship behavior. Journal of Organizational Behavior, 20(2), 159-174. https://doi.org/https://doi.org/10.1002/(SICI)1099-1379(199903)20:2\%3C159::AIDJOB881\%3E3.0.CO;2-7.

21. Salehzadeh, R., Shahin, A., Kazemi, A., \& Barzoki, A. S. (2015). Is organizational citizenship behavior an attractive behavior for managers? A Kano model approach. Journal of Management Development, 34(5), 601-620. https://doi.org/10.1108/JMD-092013-0114.

22. Scandura, T. A., Graen, G. B., \& Noval, M. A. (1986). When Managers Decide Not to Decide Autocratically: An Investigation of Leader-Member Exchange and Decision Influence. Academy of Management Proceedings, 1986(1), 203-207. https://doi.org/10.5465/ambpp.1986.4980620.

23. Schriesheim, C. A., Castro, S. L., \& Cogliser, C. C. (1999). Leader-Member Exchange (LMX) Research: A Comprehensive Review of Theory, Measurement, and Data-Analytic Practices. Leadership Quarterly, 10(1), 63-113. https://doi.org/https://doi.org/10.1016/S1048-9843(99)80009-5.

24. Shu, C. Y., \& Lazatkhan, J. (2017). Effect of leade-member exchange on employee envy and work behavior moderated by self-esteem and neuroticism. Journal of Work and Organizational Psychology, 33(1), 69-81. https://doi.org/10.1016/j.rpto.2016.12.002

25. Sparrowe, R. T., \& Liden, R. C. (1997). Process and Structure in Leader-Member Exchange. The Academy of Management Review, 22(2), 522-552. https://doi.org/https://doi.org/10.2307/259332.

26. Vera, M., Martínez, I. M., Lorente, L., \& Chambel, M. J. (2016). The Role of Co-worker and Supervisor Support in the Relationship Between Job Autonomy and Work Engagement Among Portuguese Nurses: A Multilevel Study. Social Indicators Research, 126(3), 1143-1156. https://doi.org/10.1007/s11205-015-0931-8.

27. Wagner, S. H. (2017). Exploring the Structure of Job Satisfaction and Its Impact on the Satisfaction-Performance Relationship. Journal of Organizational Psychology, 17(4), 90102.

28. Wang, L., Chu, X., \& Ni, J. (2010). Leader-member exchange and organizational citizenship behavior: A new perspective from perceived insider status and Chinese traditionality. Frontiers of Business Research in China, 4(1), 148-169. https://doi.org/10.1007/s11782-010-0007-1.

29. Wang, P. Q., Kim, P. B. C., \& Milne, S. (2017). Leader-Member Exchange (LMX) and Its Work Outcomes: The Moderating Role of Gender. Journal of Hospitality Marketing and Management, 26(2), 125-143. https://doi.org/10.1080/19368623.2016.1185989.

30. Wang, Y., Han, M. S., Xiang, D., \& Hampson, D. P. (2019). The double-edged effects of perceived knowledge hiding: empirical evidence from the sales context. Journal of Knowledge Management, 23(2), 279-296. https://doi.org/10.1108/JKM-04-2018-0245.

31. Wayne, S. J., Shore, L. M., \& Liden, R. C. (1997). Perceived organizational support and 
leadermember exchange: A social exchange perspective. The Academy of Management Journal, 40(1), 82-111. https://doi.org/https://doi.org/10.2307/257021.

32. Williams, L. J., \& Anderson, S. E. (1991). Job satisfaction and organizational commitment as predictors of organizational citizenship and in-role behaviors. Journal of Management. https://doi.org/https://doi.org/10.1177\%2F014920639101700305.

33. Wnuk, M. (2017). Organizational Conditioning of Job Satisfaction: A Model of Job Satisfaction. Contemporary Economics, 11(1), 31-44. https://doi.org/http://dx.doi.org/10.5709/ce.1897-9254.227.

34. Yu, K., Wang, Z., \& Huang, Y. (2018). Work-family conflict and organizational citizenship behavior: the role of job satisfaction and decision authority. Frontiers of Business Research in China, 12(1). https://doi.org/10.1186/s11782-018-0039-5.

35. Yukl, G. (1989). Managerial Leadership: A Review of Theory and Research. Journal of Management, 15(2), 251-289. 